\title{
SEISMIC HAZARD AND ITS MITIGATION IN NORTHEAST INDIA
}

\author{
Th.Kiranbala Devi \\ Civil Engineering Department \\ MIT,Manipur,India
}

\begin{abstract}
Being fallen the entire North Eastern states of India in the Zone $-\mathrm{V}$, the most seismic hazard zone (BIS-2002) and due to Geo- climatic condition, it is obvious that the region is highly prone to multiple natural disasters. Among these, the earthquake is the most destructive one causing huge loss of life and property. Earthquakes pose a real threat to India with 55\% of its geographical area vulnerable to seismic disturbance. Many earthquakes occurred in the past and recently had shown that major damages to the structures took place in the absence of proper design, construction and quality control. The bye law and BIS Specification were not strictly followed in many structures and suffer damages in the earthquakes.

North East India is seismically one of the six most active regions of the World, the other five being Mexico, Taiwan, California, Japan and Turkey. In the recent past there were at least 17 major earthquakes with more than M 7 during the period from 1869 to 1988. Study of the Northeastern Indian's earthquakes history and findings of seismological researches, the region is now due for a large major earthquake, which is expected in the region between the epicentre of Shillong earthquake, M-8.7 of 1897 and Patkai Range \& Arunachal Pradesh , M-7 of 1950 in the near future. Earthquake hazards of North East India cannot be changed, however disaster can be mitigated. The most important steps for mitigation of hazard is the building up of capacity in Civil Engineering and Architectural Professionals for ensuring earthquake resistant constructions. Concerning the existing buildings and structures retrofitting is one of the most important options for mitigation of disaster as most of the destructions/ damages are caused due to the collapse of structure.
\end{abstract}

Keywords: Vulnerability, Seismic hazards, Mitigation, Destruction, Retrofitting.

\section{INTRODUCTION}

India being a vast country, and more than half of its geographical area are highly vulnerable to seismic disturbance of high intensity, the country is highly vulnerable to seismic hazards. Burgeoning population and rapid urbanisation with extensive developmental works further aggravate vulnerability of seismic hazard. In the past the country has experienced several devastating earthquakes. Namely,1897 Shillong, 1905 Kangra, 1934 Bihar Nepal, 1950 Assam, 1993 Latur, 1997 Jabalpur, 1999 Chamoli, 2001 Bhuj and 2005 Kashmir, in the recent 2011 Sikkim earthquake. In recent studies it is understood that the variation of seismic hazard could be large even at local levels implying a need to incorporate the site conditions such as site response, surface geology, geomography, soil, topography, etc. Several studies on devastating earthquakes have demonstrated a large concentration of damage in specific areas due to site-dependent factors related to surface geologic conditions and local soils altering seismic motions (Borcherdt 1970; King and Tucker 1984; Aki 1988; Field et al 1992; Nath et al 2000, 2002 ; Thingbaijam 2008. On the grounds of geological and geotechnical aspects and also as the entire region falls within the zone from high to highest level of seismic hazard- the zone V, the Northeastern of India is highly vulnerable to earthquake hazard.

Geological disasters accounted for only 15 percent of the recorded events during the past 10 (ten) years, they resulted in one-third of the 300,000 fatalities. A sequence of highly destructive earthquakes between 1999 and 2004 raised the public outcry about the needlessly high number fatalities and lack of public safety afforded to public facilities, especially schools. According to a conservative estimate more than 15 million human lives have been lost and damage worth hundred billions of dollars has been inflicted in the recorded history due to earthquake (R.P Tiwari). Generally the casualties inflicted in the event of earthquakes are due to destruction of structures and buildings. Therefore structural mitigation measure, ensuring the buildings and structures to withstand the impact of earthquake by adopting the construction standard codes provided by Bureau of Indian Standard (BIS) will significantly contribute to the mitigation of seismic hazard in the region.

Many earthquakes in the past and recently had shown that major damages to the structures took place in the absence of proper design, construction and quality control. The bye laws and BIS Specification were not strictly followed in many structures and suffer damages in the earthquakes. It is not possible to prevent earthquakes from occurring. However, the disastrous effects of these can be minimised considerably through measures of scientific methods and understanding. The Northeastern region of India alone has experienced many earthquakes of magnitude 7 or more in the recent past and suffered destructions. and casualty. And in the latest, Sikkim earthquake of $18^{\text {th }}$ September of 2011, which caused heavy destruction and loss of life and how grave the region looming for an enormous seismic disaster. 
Table 1. Major Earthquake in the North Eastern Region In Recent Past:

\begin{tabular}{|c|c|c|c|}
\hline Place & Year & Magnitude & Remarks \\
\hline Cachar & March 21, 1869 & 7.8 & Numerous earth fissures and craters \\
\hline $\begin{array}{l}\text { Shillong } \\
\text { Plateau }\end{array}$ & June 12,1891 & 8.7 & About 1542 people died \\
\hline Sibasagar & August 31,1906 & 7.0 & Property Damage \\
\hline Myanmar & December 12,1908 & 7.5 & Property Damage \\
\hline Srimangal & July 8, 1918 & 7.6 & $4500 \mathrm{~km}^{2}$ area suffered damage \\
\hline SW Assam & September 9, 1923 & 7.1 & Property Damage \\
\hline Dhubri & July 2,1930 & 7.1 & $\begin{array}{l}\text { Railway lines, culverts and bridges } \\
\text { cracked }\end{array}$ \\
\hline Assam & January 27,1931 & 7.6 & Destruction of Property \\
\hline Nagaland & August 14,1932 & 7.0 & Destruction of Property \\
\hline N.E.Assam & October 23,1943 & 7.2 & Destruction of Property \\
\hline Arunachal & July7,1947 & 7.5 & Destruction of Property \\
\hline Upper Assam & August 15,1950 & 8.7 & $\begin{array}{l}\text { About } 1520 \text { people died, one of the biggest } \\
\text { known quake in the history. }\end{array}$ \\
\hline $\begin{array}{l}\text { Patkai Range, } \\
\text { Arunachal }\end{array}$ & August 15,1950 & 7.0 & Property damaged \\
\hline $\begin{array}{l}\text { Manipur } \\
\text { Burma Border }\end{array}$ & March 21, 1954 & 7.4 & Property Damaged \\
\hline Darjeeling & 1959 & 7.5 & Property damaged \\
\hline $\begin{array}{l}\text { Indo Myanmar } \\
\text { Border }\end{array}$ & August 6, 1988 & 7.5 & No casualty reported \\
\hline Sikkim & September 18,2011 & 6.9 & $\begin{array}{l}\text { Destruction of Property, loss of lives, } 67 \\
\text { dead. }\end{array}$ \\
\hline
\end{tabular}

Source: R.P.Tewari

\section{PREDICTION OF EARTHQUAKES IN NORTHEASTERN INDIA}

Earthquake prediction involves providing the time, place and magnitude of the future damaging earthquakes. The basic principles of prediction studies are (Agarwal, 2000).

- Smaller earthquakes occur more frequently than the bigger ones in any locality.

- The region, which have experienced earthquakes in the past are more prone to it.

- The bigger earthquakes are generally accompanied by smaller ones and aftershocks are more common.

- The magnitude of future earthquakes may be equal or more to the past ones.

- The earthquakes occurrence, geological data and tectonic history all have close correlation, and

Many geophysical and other parameters show anomalous changes in the wake of earthquakes.
The precise prediction of earthquakes in terms of space and time is not possible. Moreover, prediction may not helpful in avoiding or reducing damages caused by earthquakes because buildings and other structures cannot be evacuated. It can, at the most, be helpful in saving human lives. At present, status of earthquake prediction in Northeast India is that, examining the conditions and all the stated factors and following many researchers, the region is now due for a large earthquake. If we take seriously the prediction of geologist and geophysicist that Northeast would be visited by a powerful earthquake every fifty to sixty years, this is the time for a major earthquake. But the big question is when and where it will occur? And how big is it going be?. Are we prepare for such eventuality? Can the buildings in the regions withstand the impact of a great earthquake and what steps taken for mitigation of the hazard? 
International Journal of Science and Engineering Applications (IJSEA)

Volume 1 Issue 1, 2012

Table 2.Conditions of Houses in Northeast Region

\begin{tabular}{|c|c|c|c|c|c|c|c|c|c|}
\hline \multirow{2}{*}{ Assam } & \multirow{2}{*}{ Total } & \multicolumn{4}{|c|}{ Residence } & \multicolumn{4}{|c|}{ Residence Cum others } \\
\hline & & Total & Good & Liveable & $\begin{array}{l}\text { Dilapidate } \\
\mathrm{d}\end{array}$ & Total & Good & $\begin{array}{l}\text { Liveabl } \\
\mathrm{e}\end{array}$ & $\begin{array}{l}\text { Dilapidate } \\
\mathrm{d}\end{array}$ \\
\hline Urban & $9,92,742$ & $9,72,977$ & $5,74,728$ & $3,42,905$ & 55,344 & 19,765 & 10,202 & 8,720 & 843 \\
\hline \multirow[t]{2}{*}{ Rural } & $53,74,553$ & $52,99,174$ & $14,82,904$ & $31,88,056$ & $6,28,214$ & 75,379 & 18,472 & 50,217 & 6,690 \\
\hline & $63,67,295$ & $62,72,151$ & $20,57,632$ & $35,30,961$ & $6,83,558$ & 95,144 & 28,674 & \begin{tabular}{|l|l|}
4 & 58,937 \\
\end{tabular} & 7,533 \\
\hline \multirow{2}{*}{$\begin{array}{l}\text { Arunac } \\
\text { hal } \\
\text { Prades } \\
\text { h }\end{array}$} & \multirow[b]{2}{*}{ Total } & \multicolumn{4}{|c|}{ Residence } & \multicolumn{4}{|c|}{ Residence Cum others } \\
\hline & & Total & Good & Liveable & Dilapidated & Total & Good & \begin{tabular}{l|l} 
Liveabl \\
$\mathrm{e}$
\end{tabular} & $\begin{array}{l}\text { Dilapidate } \\
\text { d }\end{array}$ \\
\hline Urban & 65,891 & 63,290 & 36,922 & 24,522 & 1,816 & 2,601 & 1,635 & 940 & 26 \\
\hline \multirow[t]{2}{*}{ Rural } & $1,95,723$ & $1,91,553$ & 94,706 & 90,165 & 6,682 & 4,170 & 2,200 & 1,879 & 91 \\
\hline & $2,61,614$ & $2,54,843$ & $1,31,628$ & $1,14,717$ & 8,498 & 6,771 & 3,835 & \begin{tabular}{l|l} 
& 2,819 \\
\end{tabular} & 117 \\
\hline \multirow{2}{*}{$\begin{array}{l}\text { Manip } \\
\text { ur }\end{array}$} & \multirow[b]{2}{*}{ Total } & \multicolumn{4}{|c|}{ Residence } & \multicolumn{4}{|c|}{ Residence Cum others } \\
\hline & & Total & Good & Liveable & Dilapidated & Total & \begin{tabular}{l|l} 
Sood & \\
\end{tabular} & Liveable & Dilapidated \\
\hline Urban & $1,71,400$ & $1,66,761$ & $1,06,068$ & 53,289 & 7,404 & 4,639 & 2,559 & 1,802 & 278 \\
\hline \multirow[t]{2}{*}{ Rural } & $3,35,752$ & $3,31,382$ & $1,63,721$ & $1,52,014$ & 15,647 & 4,370 & 203 & 1,986 & 181 \\
\hline & $5,07,152$ & $4,98,143$ & $2,69,789$ & $2,05,303$ & 23,051 & 9,009 &, 762 & 3,788 & 459 \\
\hline \multirow{2}{*}{$\begin{array}{l}\text { Megha } \\
\text { laya }\end{array}$} & \multirow[t]{2}{*}{ Total } & \multicolumn{4}{|c|}{ Residence } & \multicolumn{4}{|c|}{ Residence Cum others } \\
\hline & & Total & Good & Liveable & Dilapidate & Total & Good & \begin{tabular}{l|l} 
Liveabl \\
$\mathrm{e}$
\end{tabular} & Dilapidate \\
\hline Urban & $1,16,102$ & $1,14,366$ & 79,718 & 31,539 & 3,109 & 1,736 & 1,009 & 658 & 69 \\
\hline \multirow[t]{2}{*}{ Rural } & $4,22,197$ & $4,18,270$ & $1,76,386$ & $2,13,001$ & 28,883 & 3,927 & 1,632 & 2,071 & 224 \\
\hline & $5,38,299$ & $5,32,636$ & $2,56,104$ & $2,44,540$ & 31,992 & 5,663 & 2,641 & 2,729 & 293 \\
\hline
\end{tabular}

\begin{tabular}{|c|c|c|c|c|c|c|c|c|c|}
\hline \multirow{2}{*}{$\begin{array}{l}\text { Mizora } \\
\mathrm{m}\end{array}$} & \multirow{2}{*}{ Total } & \multicolumn{4}{|c|}{ Residence } & \multicolumn{4}{|c|}{ Residence Cum Others } \\
\hline & & Total & Good & Liveable & $\begin{array}{l}\text { Dilapidate } \\
\mathrm{d}\end{array}$ & Total & Good & $\begin{array}{l}\text { Liveabl } \\
\mathrm{e}\end{array}$ & $\begin{array}{l}\text { Dilapidate } \\
\text { d }\end{array}$ \\
\hline Urban & $1,16,203$ & $1,14,397$ & 84,366 & 28,314 & 1,717 & 1,806 & 1,204 & 574 & 28 \\
\hline \multirow[t]{2}{*}{ Rural } & $1,04,874$ & $1,03,281$ & 51,301 & 47,514 & 4,466 & 1,593 & 910 & 662 & 21 \\
\hline & $2,21,077$ & $2,21,678$ & $1,35,667$ & 75,828 & 6,183 & 3,399 & 2,114 & 1,236 & 49 \\
\hline \multirow{2}{*}{$\begin{array}{l}\text { Nagala } \\
\text { nd }\end{array}$} & \multirow{2}{*}{ Total } & \multicolumn{4}{|c|}{ Residence } & \multicolumn{4}{|c|}{ Residence Cum others } \\
\hline & & Total & Good & Liveable & $\begin{array}{l}\text { Dilapidate } \\
\mathrm{d}\end{array}$ & Total & Good & $\begin{array}{l}\text { Liveabl } \\
\mathrm{e}\end{array}$ & $\begin{array}{l}\text { Dilapidate } \\
\mathrm{d}\end{array}$ \\
\hline Urban & $1,15,054$ & $1,12,776$ & 69,999 & 40,641 & 2,136 & 2,278 & 1,383 & 854 & 41 \\
\hline \multirow{2}{*}{ Rural } & $2,84,911$ & $2,82,576$ & $1,37,084$ & $1,40,458$ & 5,034 & 2,335 & 1,225 & 1,089 & 21 \\
\hline & $3,99,965$ & $3,95,352$ & $2,07,083$ & $1,81,099$ & 7,170 & 4,613 & 2,608 & 1,943 & 62 \\
\hline \multirow[b]{2}{*}{ Sikkim } & \multirow[b]{2}{*}{ Total } & \multicolumn{4}{|c|}{ Residence } & \multicolumn{4}{|c|}{ Residence Cum others } \\
\hline & & Total & Good & Liveable & Dilapidated & Total & Good & Liveable & Dilapidated \\
\hline Urban & 35,761 & 34,099 & 27,383 & 6,106 & 610 & 1,662 & 1,330 & 314 & 18 \\
\hline \multirow[t]{2}{*}{ Rural } & 92,370 & 89,730 & 41,907 & 41,572 & 6,251 & 2,640 & 1,822 & 747 & 71 \\
\hline & $1,28,131$ & $1,23,829$ & 64,290 & 47,678 & 6,861 & 4,302 & 3,152 & 1,061 & 89 \\
\hline \multirow[t]{2}{*}{ Tripura } & Total & \multicolumn{4}{|c|}{ Residence } & \multicolumn{4}{|c|}{ Residence Cum others } \\
\hline & & Total & Good & Liveable & Dilapidated & Total & Good & Liveable & Dilapidated \\
\hline Urban & $8,42,781$ & $2,31,422$ & $1,47,716$ & 73,933 & 9,773 & 3,580 & 1,810 & 1,607 & 163 \\
\hline Rural & $6,07,779$ & $5,98,083$ & $3,04,452$ & $2,61,729$ & 31,902 & 9,696 & 3,147 & 5,690 & 859 \\
\hline & $8,42,781$ & $8,29,505$ & $4,52,168$ & $3,35,662$ & 41,675 & 13,276 & 4,957 & 7,297 & 1,022 \\
\hline
\end{tabular}

Source:Housing sensus of India 
The above table shows with few number of houses in good shape as well as a good number of houses in dilapidated condition in Assam, where great earthquakes struck many times. The conditions of houses in Meghalaya and Sikkim which have experienced the devastation of destructive earthquakes are indeed need for assessment of the buildings. The most important question is how safety are the buildings and structures in these region where earthquakes of low to very high intensity were frequented.

\section{MITIGATION OF STRUCTURES: 3.1 New Buildings:}

Most casualties during earthquakes are caused by the collapse of structures. Therefore structural mitigation measures are the key to make a significant towards earthquake safety in the region. In view of this the states in earthquake prone zones must review and if necessary, amend their building bye-laws to incorporate the BIS Seismic Codes for construction in the concerned zones. The Indian codes, developed by the Bureau of Indian Standards (BIS), are not mandatory and are only in the nature of guidelines. The construction as such is governed by the Municipal bye-laws which are within the jurisdiction of the state government. Unfortunately, the seismic provisions have not been incorporated in to the building bye-laws. Majority of the building construction activity in the country including the region of high seismic zones is carried out in an informal manner with no involvement of engineers; most of it is done with no regard to seismic safety. The Government departments and Public sector organisations manage a large fraction of the formal sector construction and are formally committed to follow the codes. However, even in such organisations, the seismic aspects do not get due attention. The situation is similar even when professional consultants are involved in a project. Such attitude need to have change and conformity of IS Codes for constructions with legal provisions must be enforced. The country has failed miserably in ensuring earthquake resistant construction in high seismic regions, the result we have experienced in Bhuj earthquake, 2001 and Sikkim earthquake, 2011. As Northeastern region is highly seismic and experienced two great earthquakes of 1897 and 1950, the people here learnt to construct flexible and sufficiently earthquake proof houses popularly known as "Assam Type" (Nandi; 1999). Now, the scenario has changed and these houses paved the way for multi-storey RCC buildings particularly in the capital towns of all the States of the region. If the present trend of construction and population growth is continues, the earthquake of Magnitude > 7.5 will bring enormous damage to property and great loss of lives. Therefore, the administrative agencies have to strictly enforce the implementation of proper building codes and appropriate land use policy in the region.

\subsubsection{Increase in the Cost: Since the trend of high-} rise buildings is growing up rapidly in the cities especially in Guwahati, in the region, latest technology is required to build these structures. However, for all other structures existing knowledge is by and large sufficient. People fear that construction costs will increase significantly when they go for resistant designs. It is true, percentage of steel consumption increase significantly up to $25 \%$ to $40 \%$ but this only when we compare steel consumption in column. If we compare the cost with overall cost of the construction then it will be well within 5\%. Therefore correct steps and proper investment should be taken up in building of such high-rise for the safety of the future generation.

\subsection{Retrofitting of Buildings}

The need for seismic retrofitting of building arises for the hazard mitigation of the society. The necessity of retrofitting of earthquake vulnerable buildings may be done due to many reasons such as buildings that have been designed according to older seismic codes; buildings of great values or importance like hospitals, monuments, buildings suffered damages in the previous earthquakes or other and buildings which is essentially to be used just after the earthquake. While mitigation measure will take care of the new constructions, the problem of unsafe existing building stock would still remain. It will not be possible to address the entire existing building stock, therefore the life line buildings like hospitals, schools or buildings where people congregate like cinema halls, multi-storied apartments are being focussed on. The assessment of the buildings and selection of appropriate retrofitting methods is itself a great challenge to the engineers.

\section{SIKKIM EARTHQUAKE, 2011}

Earthquake of magnitude of 6.9 on Richter Scale struck Sikkim on September 18, 2011. This earthquake caused huge destruction of property and loss of lives. Sikkim one of the states of Northeast India falls in the seismic Zone-IV, while other states of the region in the highest seismic risk Zone-V. Study of the destructions and aftermath of the earthquake hazard will definitely help in the planning of seismic mitigation in this region.

- $\quad$ total number of houses were damaged in varying degree; 4,125 houses were completely destroyed; 17,026 houses required major repairing and 21,929 needed minor repairing.

- Out of a total of 779 schools in the States, 682 schools were damaged. Children fall in vulnerable group and children in primary classes are more vulnerable to disasters. Hence, in the case of Sikkim, since all schools have primary classes, they all become more vulnerable. Hence, adequate and comprehensive measures for retrofitting and strengthening of the damaged as well as the undamaged schools required prompt execution, even if it means reconstructing.

- Gangtok, besides being the capital of the State is also its most populated city with maximum infrastructure. Most of the buildings withstand the quake on that fateful night, except the main secretariat, police headquarters and school buildings. The State Government should get an audit of all its buildings carried out to check for structural faults and get them rectified, even if it means reconstructing some of the buildings as in the case of schools. One cannot forget that while 
the earthquake brought much destruction in the northern part of the state, in other less affected regions there are thousands of buildings that are not disaster resilient. Hence, they are just vulnerable, and succumb easily in a future quake in these regions. Such shortcomings should be addressed and strengthened for mitigation of seismic hazard.

\section{CONCLUSION}

Northeast India is highly vulnerable for earthquakes, which cannot be prevented from occurring. Therefore, we have to learn to live the earthquake hazard looming and try to minimise its adverse impact on human civilisation. Earthquake hazard is one the most deadly phenomenon which claims the lives of large number of person without any warning. These deadliest destructions were mainly caused due to the collapse of structures and buildings. Hence, to mitigate the destruction of this natural disaster it is high time that people start adopting IS codes for earthquake resistant designs in the construction of buildings and structures we dwelt. Concerted efforts of the planners, administrators, engineers, architects, builders, promoters, financer etc. with strict enforcement of building codes for construction of masonry structures, even for small housing complex in the earthquake prone zones and strict legislation of land use may help in the mitigation of earthquake hazards

\section{REFERENCES:}

[1]Agarwal,P.N.(2000), Seismological Aspects of Earthq uake Reduction. Sixth IGC Foundation Lecture, IGC, pp.119.

[2]Aki, (1988), Local sites effects on ground motion in Earthquake Engineering and Soil Dynamics II - Recent Advance in Ground motion evaluation; American Society for Civil Engineering and Geotechnical, Special publication, Vol. 20, pp.103-155.

[3]Bapat,A (1996), Creation of awareness about earthquakes- Case Histories. Proc. Int. Conf. On Disaster and Mitigation, Madras,1:A1-A13

[4] Borcherdt, R.D.(1970),Effects of local geology on ground motion near San Francisco Bay; Bulletin of Seismological Society of America, Vol. 60, pp.29-61.

[5]Durgesh C Rai,(2000), Future trends in earthquake resistant design of structure; Current Science. Voll-79,No.9, 10 Nov.2000, pp.1291-1300.

[6]Dr.Ramancharla Pradeepkumar, PhD, (2010), Can earthquake be predicted?; Master Builder, October 10, Vol. V.12.No.10,pp.158-160

[7]Dr.Th.Kiranbala Devi, PhD,(2011), Earthquake Disaster Mitigation; Proceedings of International Conference on Advances in Materials and Techniques for Infrastructures
Development, 28-30 September,2011, NIT Calicut, Kerala, India.

[8] Field E H, Jacob K H and Hough S H (1992); Earthquake site response estimation: a weak motion case study, Bulletin of Seismological Society of America, Vol. 82, pp.2283-2307.

[9]Gautam Prasad Baruah, Are We Prepare for an Earthquake in Northeast?, http://gpbaroowah.blogspot.in

[10]Housing Census of India; 2011

[11] IS 4326:1993, Revised, (2002-2004) BIS 2002.

Earthquake Resistant Design And Construction of Buildings- Code of Practice, ( Second Revision)

[12] IS 1893 (Part 1):2002 : Criteria for Earthquake Resistant Design of Structures.

[13]Kayal,J.R.(1996), Earthquake Source Process in NorthEast India: A review.Him. 17:53-69

[14] Khattri,K.N. (1987), Great earthquakes, seismicity gaps and potential for earthquake disaster along the Himalayan Plate boundary, Techtophysics, 138:79-93

[15]Khattri, K.N. (1993) : Seismic gaps and likelyhood of occurrence of larger earthquake in Northeast India, Current Science, 64 (11\&12) : pp. 885-888.

[16] Khattri, K.N. \& Weiss, M. (1978) : Precusory variation of seismic rate in Assam area,India, Geology, 6: pp. 685688.

[17] King J .L. and B.E. Tucker, (1984), Observed variation of earthquake motion across a sediment-filled valley. Bulletin of Seismological society of America, Vol.74, pp.137-151.

[18]Nath S.K,, Sengupta P, Sengupta S and Chakrabarti A,(2000), Site response estimation using strong motion network, A step towards micronization of Sikkim Himalayas; Seismology, Current Science Vol.79, pp.13161326.

[19]Nath SK, Biswas NN, Dravinski M and Papageorgion A,(2002 a); Determination of $S$ Waves site response in Anchorage, Alaska in the $1-9 \mathrm{~Hz}$ frequency band; Pure Appl. Geophysics, Vol.159, pp.1071-1081.

[20]Nath SK, Sengupta $P$ and Kayal JR,(2002 b),Dtermination of site response at Garhwal Himalaya from the after shock sequence of 1999 Chamoli earthquake; Bull.Seism.Soc.Am.;Vol.82, pp.24-43.

[21]Nina Khanna, Jayender Verma \& B.K.Khanna, Journel of Defence Studies, Vol. 6 No. 1 January 2012, pp. 77-90. 
[22]R.P.Tiwari, (2010), Status of Seismicity in the Northeast India and Earthquake disaster Mitigation. pp.114.

[23]R.P.Tiwari,(2000), Earthquake Hazards and Its Mitigation in India with special reference to North Eastern Region.ENVIS Bulletin, 8(2); pp.15-22.

[24]Sankar Kumar Nath, Kiran Kumar Singh Thingbaijam \& Abhishek Raj, J. Earth Syst. Sci, 117,S2November,2008, pp- 809- 839
[25] Sudhir K Jain \& Navin C. Nigam,(2000), Historical Developments and Current Status of Earthquake Engineering in India), - Proceedings of the $12^{\text {th }}$ World Conference on Earthquake Engineering, Aukland, New Zealand.

[26]United Nations;(2005); World Conference on Disaster Mitigation, 18-22 January, Kobe, Hyogo, Japan.

[27]yokohama strategy and plan of action for safer world: guidelines for natural disaster prevention, preparedness and mitigation, world conference on natural disaster mitigation, Yokohama, Japan, 23-27 May 1994. 